\title{
CONTRACT CARRIAGE BY COMMON CARRIERS UNDER THE SHIPPING ACT OF 1916*
}

Tere Court of Appeals for the Second Circuit recently decided that the policies underlying the Shipping Act of $1916^{1}$ required a broad definition of the statutory term "common carrier." By this Act regulating "common carriers by water in foreign commerce," 2 Congress sought to promote stable rates and regular sailings along trade routes essential to the foreign commerce of the United States by eliminating the rate wars and discriminatory practices that had previously characterized the shipping business. ${ }^{3}$ The statute established a regulatory board to countervail the monopoly power of the regular shipping lines. ${ }^{4}$ Tramp shipping-by its very nature unscheduled, sporadic and competitive ${ }^{5}$-was specifically excluded from the Act's coverage. ${ }^{6}$ As a means of identifying these two segments of the shipping industry the statute relies on the common law distinction between a "common carrier" and a "contract carrier."'

At common law one who transported goods became a common carrier only to the extent that he held himself out either by words or actions as ready to accept goods from the general public. ${ }^{8}$ While every transporter had the right to limit the scope of his public undertaking either to particular commodities or geographically, as between two termini, ${ }^{9}$ a common carrier was obliged to ac-

*Grace Line, Inc. v. Federal Maritime Board, 280 F.2d 790 (2d Cir. 1960), cert. denied, 364 U.S. 933 (1961).

1. 39 Stat. 728 (1916), as amended, 46 U.S.C. $\$ \$ 801-42$ (1958).

2. 39 Stat. 728 (1916), as amended, 46 U.S.C. $\$ 801$ (1958).

3. House Comimittee on the Merchant Marine and Fisheries, 63rd Cong., 2d Sess., Report on Steasiship Agreenents and Affiliations in the Adrerican Foreign and Domestrc Trade 415-21 (1914) [hereinafter cited as Alexander Consmirtee RePORT] (recommendations quoted in full with approval in H.R. REP. No. 659, 64th Cong., 1st Sess. 27-31 (1916) and in S. Rep. No. 689, 64th Cong., 1st Sess. 7-11 (1916)). See Alexander Comisitite Report 307-14.

4. See Alexander Connittee Report 415-21.

5. See McGee, Ocean Freight Rate Conferences and the American Merchant Marine, 27 U. CHI. L. REv. 191, 205-06 (1960).

6. Shipping Act $\S 1,39$ Stat. 728 (1916), 46 U.S.C. $\$ 801$ (1958).

7. See Hearings on H.R. 14337 Before the House Committee on the Merchant Marine and Fisheries, 64th Cong., 1st Sess. $194-97$ (1916) ; 53 Cong. REc. 8267-68 (1916).

8. 1 Hutchinson, Carriers $\$ \$ 47,49,59,90$ (3d ed. 1906); 1 D. C. Moore, Carriers 19 (2d ed. 1914).

Thus the question becomes important as to whether one carrying goods is a private or a common carrier, and the answer is held to depend on whether the carrier has held himself out, expressly or impliedly, as willing to carry the particular class of goods between the points of carriage for all who may apply to him, indiscriminately and without differentiation, for thus only does his employment become common and public in character, and the one who has not put himself within this definition is held a private carrier.

Elitotr, BaILMiENTS § 124 (2d ed. 1929).

9. Dobie, BailMrents \& CarrIers § 110 (1914). 
cept on equal terms all those goods that came within his express or constructive holding out. ${ }^{10}$ Moreover, a general common carrier-one who did not limit his holding out-could not arbitrarily exclude any item customarily transported by common carriers from his common carriage. ${ }^{11}$ Whereas the common carrier held out his services to all, the contract carrier deliberately restricted his business to a few, and limited his obligations by individual contract. ${ }^{12} \mathrm{~A}$ single carrier could act as both a contract and a common carrier. ${ }^{13}$ When a common carrier accepted an item for a few shippers only, an item not within his general offer to the public, he became a contract carrier with respect to that item. ${ }^{14}$ Conversely, a contract carrier could act as a common carrier with regard to some items. ${ }^{15}$ In determining whether a given transporter was acting within his public holding out a number of criteria have been employed by the courts. General advertising, a history of carrying a wide variety of goods, a large number of, or frequent turnover in, customers, all tended to prove a general holding out. ${ }^{18}$ On the other hand, if a carrier had always carried a particular item under special contract and for a few shippers only, this would tend to prove that with regard to that item he was acting as a contract carrier. ${ }^{17}$ In addition, a common carrier could act as a contract carrier when he handled goods requiring unusual care, ${ }^{18}$ never before carried at common carriage, or never before carried by him at common carriage. ${ }^{10}$

10. Memphis News Pub. Co. v. Southern Ry. Co., 110 Tenn. 684, 75 S.W. 941 (1903); 2 Hutchinson, Carriers $\$ \S 512$, 520-21 (3d ed. 1906); 1 Moore, Carriers 19-23 (2d ed. 1914); Dobie, Bailments \& Carriers $\$ 115$ (1914).

11. 1 Moore, CarrIers 116-17 (2d ed. 1914).

12. 1 Hutchinson, Carriers $\$ 35$ (3d ed. 1906); Dobte, Batlments \& Carriers $\$ 106$ (1914); 1 MOORE, CarrIERs 3-4 (2d ed. 1914).

13. Express Cases, 117 U.S. 1 (1885) ; United States v. Louisville \& Nashville R.R., 221 F.2d 698, 703 (6th Cir. 1955) ; Lake Shore \& Michigan So. R.R. v. Perkins, 25 Mich. 329 (1872) ; Manufacturers Ry. v. St. Louis, Iron Mountain \& So. Ry., 21 I.C.C. 304 (1911) ; Ney v. Haun, 131 Va. 557, 109 S.E. 438 (1921) ; Roberts v. Chicago R.I. \& P.R.R., 99 F. Supp. 895 (D. Minn. 1951) ; Cleveland, C., C. \& St. L. Ry. v. Henry, 170 Ind. 94, 83 N.E. 710 (1908).

In particular, see Pan-Atlantic Steamship Corp.-Exemption, Section 303 (e), 285 I.C.C. 752 (Div. 4, 1956) (where a carrier was both a common and a contract carrier on the same vessel). But sec Transp. by Mendez \& Co., 2 U.S.M.C. 717, 721 (1944) (dictum).

14. Ellyotr, BaIlasents $\$ 126$ (2d ed. 1929) and cases cited in note 13 supra.

15. 53 Cong. REc. $\$ 628$ (1916).

16. Transocean Air Lines, Inc., Enforcement Proceedings, 11 C.A.B. 350, 352-58 (1950) ; Transportation Activities of Midwest Transfer Co., 49 M.C.C. 383 (1949), aff'd, 51 M.C.C. 355 (1950) ; N.S. Craig Contract Carrier Application, 31 M.C.C. 705, 707-13 (1941).

17. Transocean Air Lines, Inc., Enforcement Proceedings, 11 C.A.B. 350, 352-58 (1950) ; Michigan Pub. Util. Comm'n v. Duke, 266 U.S. 570 (1925).

18. United States v. Louisville \& Nashville R.R., 221 F.2d 698, 703 (6th Cir. 1955); N.S. Craig Contract Carrier Application, 31 M.C.C. 705, 707-13 (I.C.C. 1941) ; Transportation Activities of Midwest Transfer Co., 49 M.C.C. 383 (Div. 5, 1949), aff'd, 51 M.C.C. 355 (I.C.C. 1950) ; Michigan So. \& No. Ind. R.R. v. McDonough, 21 Mich. 165 (1870).

19. Michigan So. \& No. Ind. R.R. v. McDonough, 21 Mich. 165, 200-01 (1870). Of course, if this argument were to be followed to extremes the business of common carriage 
While at common law one was a common carrier only to the extent of his public holding out, ${ }^{20}$ the underlying policy of the Shipping Act suggests that a broader use of the term was intended in the statute. ${ }^{21}$ By using the term "common carriers" Congress may have intended to exert federal control over the activities of shipping lines with respect to all goods carried on regularly scheduled vessels, regardless of whether at common law the transportation of some of those goods would have been considered contract carriage. ${ }^{22}$ On the other hand, the legislative history may indicate that "common carrier" in the Act is to be read in the light of its common-law definition. ${ }^{23}$ Neither the courts nor the Federal Maritime Board have ever squarely resolved this conflict: does "common carrier" simply codify the common law meaning, or does it signify a more comprehensive congressional regulation of shipping?

In Grace Line, Inc. v. Federal Maritime Board ${ }^{24}$ two banana importers instituted proceedings before the Federal Maritime Board alleging that the Grace Line was a common carrier of bananas from Guayaquil, Ecuador to New York and that it unjustly discriminated against them by refusing to allocate space for their bananas. ${ }^{25}$ The Grace Line opposed the Board's jurisdiction on the ground that the Line had never held itself out to carry bananas for the public and that

would never grow to meet new conditions. Naturally, the fact that a carrier has never, or that no carrier has ever, carried an item is only one factor to be considered along with others as to whether or not a carrier has constructively held himself out to carry a particular item.

20. See notes 8-10 supra and accompanying text.

21. See notes $3 \& 4$ supra and accompanying text.

22. The Alexander Conmitree Refort speaks throughout of the need to regulate shipping lines and regularly scheduled vessels. It does not speak in terms of common or contract carriers.

23. See 53 Cong. Rec. 8267-68 (1916), Hearings Before the Honse Committee on the Merchant Marine and Fisheries, 64th Cong., 1st Sess. 194-97 (1916) (brief on the subject of when one is a common carrier and when a private or contract carrier). Indeed, the Federal Maritime Board concedes that "the term 'common carrier' is not defined in the Act, but [that] the legislative history of the Act indicates that the person to be regulated is the common carrier at common law." Banana Distribs., Inc. v. Grace Line, Inc., 5 F.M..B. 615,620 (1959) (the second report of the Board in the Grace case).

24. 280 F.2d 790 (2d Cir. 1960), cert. denied, 364 U.S. 933 (1961).

25. Banana Distribs., Inc. v. Grace Line, Inc., 5 F.M.B. 278 (1957). The plaintiffs urged on the Board violations of $\$ \S 14$ and 16 of the Shipping Act of 1916, 39 Stat. 733, 734 , as amended, 46 U.S.C. $\$ \$ 812,815$ (1958), the pertinent portions of which are:

Sec. 14. That no common carrier by water shall directly or indirectly-

Fourth. Make any unfair or unjustly discriminatory contract with any shipper based on the volume of freight offered, or unfairly treat or unjustly discriminate against any shipper in the matter of (a) cargo space accommodations or other facilities, due regard being had for the proper loading of the vessel and the available tonnage. ...

Sec. 16. That it shall be unlawful for any common carrier by water, or other person subject to this Act, either alone or in conjunction with any other person, directly or indirectly-

First. To make or give any undue or unreasonable preference or advantage to any particular person locality, or description of traffic in any respect whatsoever, or to 
it was therefore a contract, and not a common, carrier of bananas. ${ }^{26}$ The Federal Maritime Board held, however, that the Grace Line was a common carrier of bananas, and directed Grace to prorate its existing space among all interested, qualified banana shippers. ${ }^{27}$ The Second Circuit reversed, holding that the Board's finding arose from an erroneous test. ${ }^{28} \mathrm{On}$ remand the Board again found the Grace Line subject to the Act as a common carrier of bananas, this time "without reference to the [erroneous] test." 29 A divided Court of Appeals affirmed the Board's second report and order. ${ }^{30}$

The Second Circuit held that the Grace Line's carriage of bananas was subject to the provisions against discrimination in the Shipping Act. ${ }^{31}$ The court accepted the test that at common law a carrier becomes a common carrier only when it holds itself out as such, and that a common carrier may on occasion act as a contract carrier. Judge Hand, speaking for the majority, did not make a finding as to whether the Grace Line would have been a contract carrier of bananas at common law, privileged to discriminate among shippers. However, the court assumed, arguendo, that the Grace Line would have been so privileged at common law. Nevertheless, Hand's opinion rejects the Grace Line's argument that the Act regulates common carriers only while they are acting as such. It specifically discards the common law test of "holding out" as a limitation on the Board's jurisdiction. To allow the Grace Line in its capacity as a contract carrier to discriminate among shippers, Judge Hand argued, might impair the maintenance of a merchant marine and violate the declared policy of the Act. ${ }^{32}$ The court concluded that the underlying policy of the Act compelled it to look beyond fine common law distinctions.

It appears to us that when Congress enacted authoritative supervision over the equal treatment of shippers it could not have meant to perpetuate what so far as it may perhaps still exist at common law, would be an exception to the primary purpose of the statute as a whole. ${ }^{33}$

The Second Circuit's holding thus extends the coverage of the Shipping Act to the contract carrier activities of common carriers.

Judge Hand's opinion may be inconsistent with the policy underlying the Shipping Act in so far as it implies that all the activities, whether contract or

subject any particular person, locality or description of traffic to any undue or unreasonable prejudice or disadvantage in any respect whatsoever.

Certain other charges, originally alleged, were not pressed or considered by the Board. Banana Distribs., Inc. v. Grace Line, Inc., supra.

26. Banana Distribs., Inc. v. Grace Line, Inc., 5 F.M.B. 278, 280 (1957).

27. Id. at 284-86.

28. Grace Line, Inc. v. Federal Maritime Board, 263 F.2d 709, 711 (2d Cir. 1959).

29. Banana Distribs., Inc. v. Grace Line, Inc., 5 F.M.B. 615, 617 (1959).

30. Grace Line, Inc. v. Federal Maritime Board, 280 F.2d 790 (2d Cir. 1960), ert. denicd, 364 U.S. 933 (1961).
31. Ibid.
32. Id. at 792 .
33. Id. at 793 . 
common, of a common carrier are subject to regulation. ${ }^{34}$ Congress desired to regulate only the carriage of goods in regularly scheduled vessels, where it thought that competition was incapable of protecting the public's interests because of the monopoly power of the regular shipping lines exercised through conference agreements. ${ }^{35}$ Thus, for example, Congress apparently did not intend the Act to cover a carrier when it leased out an entire ship. ${ }^{36}$ For in such a situation the shipping company is acting outside the regular carriage market, and is in an area of tramp carriage where Congress felt competition would operate to eliminate discrimination and to maintain reasonable rates. Moreover, the explicit exemption in the Act for tramp steamers also suggests that Congress did not intend to regulate the tramp activities of a regular shipping line. ${ }^{37}$

In addition to leaving a common carrier unregulated when it leased out an entire vessel, arguably, Congress did not intend the Act to cover any of the other contract carrier activities of regularly scheduled shipping lines. ${ }^{38}$ The Federal Maritime Board and its predecessor, the Maritime Commission, have consistently held that the legislative history of the Act indicates that Congress intended to codify the common law definition of "common carrier."30.Moreover, the Supreme Court has declared that the Shipping Act was patterned after the Interstate Commerce Act of 1898 and its terms should be similarly construed. ${ }^{40}$ Under that Act common carriers were not regulated with respect to activities which would have been considered contract carriage at common law. ${ }^{41}$

34. It is only when a vessel engages in business as a common carrier that it comes within the provisions of this bill. Where a ship is let by charter party to a person who is to furnish a full cargo, the owners having no right to take goods for any other person, it is not a common carrier, but only a bailee to transport as a private carrier for hire.

53 Cong. Rec. 13365 (1916) (remarks by Representative Alexander). See also 53 CoNG. REc. 8267-68 (1916).

35. See notes 4-6 \& 22 supra and accompanying text.

36. See note 34 supra.

37. Shipping Act $\S 1,39$ Stat. 728, as amended, 46 U.S.C. $\$ 801$ (1959) ("an ocean tramp shall not be deemed [a] 'common carrier by water" ").

38. For when a common carrier engages in contract carriage, he becomes a contract carrier of that item and is not, with respect to that item, a common carrier. See notes $13 \&$ 14 sipra.

39. Banana Distribs., Inc. v. Grace Line, Inc., 5 F.M.B. 615, 620 (1959); Galveston Chamber of Commerce v. Saguenay Terminal, 4 F.M.B. 375, 378 (1954); United States Gulf-Atlantic and India, Ceylon and Burma Conference (Agreement No. 7620) 2 U.S. M.C. 749, 752 (1945).

See Representative Alexander's brief on the legal status of tramp vessels in Hearings on H.R. 14337 Before the Honse Committee on the Merchant Marine and Fisheries, 64th Cong., 1st Sess. 194-95 (1916). See also 53 Cong. REc. 8267-68, 13365 (1916).

40. United States Nav. Co. v. Cunard S.S. Co., 284 U.S. 474, 480-81, 484 (1932).

Congress repeatedly emphasized that the Shipping Act was closely modelled on the Interstate Commerce Act. 53 Cong. Rec. 12351, 12448. See Alexander Commitree Refort 415-21, quoted with approval in H.R. Rer. No. 659, 64th Cong., 1st Sess. $27-31$ (1916) and in S. REP. No. 689, 64th Cong., 1st Sess. 7-11 (1916).

41. United States v. Louisville \& N.R.R., 221 F.2d 698, 703 (6th Cir. 1955); cf. 
The broad policy underlying the Shipping Act and the structure of the industries regulated by the Interstate Commerce Act cut against the arguments for a restrictive interpretation of "common carrier." In the area of railroad transportation, the relative infrequency of contract carriage of any type meant that in regulating common carriers Congress was unavoidably regulating an entire industry. ${ }^{42}$ The need to distinguish between types of carriage was less significant under that statute. The Interstate Commerce Act, therefore, may not provide a reliable guide for construing the term "common carrier" in the Shipping Act, by which Congress clearly intended only partial regulation of the shipping industry. In addition a balance must be struck between the actual words of the Act and the policy underlying them. When a court is confronted with a statutory term it must often choose between a narrow construction in conformity with the common law meaning, and a broad construction which better implements the purpose of the enactment. Although older rules of statutory construction called for "a rather strict interpretation" of grants of power, ${ }^{43}$ the more recent and better rule favors a broad interpretation advancing the "objectives and purposes for which the legislation was enacted." 44

Given a policy favoring the regulation of regular shipping lines, 45 the present economic structure of the industry provides a strong rationale for regulating all the contract carrier activities of these lines. In order to promote the development of regularly scheduled American shipping, Congress provides substantial subsidization for vessels in this trade, ${ }^{46}$ and also permits their owners to form cartels ${ }^{47}$ as a means of protecting the regular carriage of goods against the distuptive competition of tramp steamers. In addition, the Federal Maritime Board is authorized to permit these cartels of common carriers to employ a discriminatory rate schedule against those doing business with tramp steamers. ${ }^{48}$ By virtue of this governmentally protected position, and by virtue of the discriminatory rates permitted, common carriers may have a substantial advantage over tramp steamers in the shipment of goods customarily offered for trans-

Terminal Taxicab Co. v. Public Util. Comm'n, 241 U.S. 252 (1916) (where the Court construed the regulatory scope of the term "common carrier" not to include the contract activities of those common carriers under a different statute).

42. Railroads are almost by the very act of their creation subject to the duties of a common carrier and only in special circumstances may they act as contract carriers. See generally 1 MOORE, CARrIers 115-67 (2d ed. 1914).

43. See 3 Sutherland, Statutory Construction $\S 6603$ (3d ed. 1943).

44. See id. at $\S 6604$ (3d ed. 1943).

45. See McGee, Occan Freight Rate Conferences and the Anterican Merchant Marine, 27 U. CHI. L. REv. 191 (1960), which casts doubt upon the advisability of our whole regulatory policy toward ocean shipping.

46. Merchant Marine Act, 49 Stat. 1985 (1936), as amended, 46 U.S.C. $\$$ 1101-1294 (1958).

47. See Shipping Act $\$ 15,39$ Stat. 728, 733 (1916), as amended, 46 U.S.C. $\$ 814$ (1958).

48. Shipping Act $\S 14,39$ Stat. 728,733 (1916), as amended, 46 U.S.C. $\$ 812$ (1958), as amended, 74 Stat. 253 (1960), 46 U.S.C.A. $\$ 812$ (Supp. 1961). 
portation on regularly scheduled vessels. ${ }^{49}$ Moreover, this advantage may extend beyond regularly scheduled shipping to the leasing out of an entire ship. Because of their control over the shipment of general cargo, common carriers may have a strong economic lever not only in securing special cargo for regularly scheduled vessels but also in obtaining bulk cargo for carriage by charter. ${ }^{50}$ Congressional protection of common carriers, however, was designed only to promote regularly scheduled sailings, and not to provide common carriers engaged in contract carriage with an advantage over tramp steamers. And to permit the common carriers to retain this advantage and at the same time to remain unregulated would be contrary to congressional policy.

Though it might be best if all the contract carrier activities of common carriers were placed under the jurisdiction of the Federal Maritime Board, direct congressional resolution of the ambiguity in the Shipping Act may be preferable to judicial extension of the statute. ${ }^{51}$ Affecting foreign as well as American flag lines, the Shipping Act has important consequences on our foreign relations. A court might be well advised, therefore, to require Congress to confront anew the fundamental policy question of the extent to which public control should be exerted over the shipping industry. If there is to be federal regulation of the contract carrier activities of common carriers, whether by judicial construction or legislative resolution, the Board itself should in each case consider the impact of its decision on the structure of our foreign commerce, and on the economies of foreign nations potentially involved. The Board should also examine closely the possible effect of its orders on the shipping industry as a whole, and on the domestic market of the commodity involved in the litigation. Will the contemplated decree raise costs, expand the supply of the goods in question, induce more trade, encourage healthy competition and the development of a national merchant marine ?52 The extent to which the Board considered these factors in the Grace Line case is unclear. Even if they are involved $s u b$ silentio in its decision, good administrative law practice requires that they be articulated in the opinion accompanying the decree. ${ }^{53}$

Regardless of whether the Grace Line would have been considered a contract carrier of bananas at common law, ${ }^{54}$ it would be inconsistent with the purposes

49. Cf. McGee, Ocean Freight Rate Conferences and the American Merchant Marine, 27 U. CHI. L. REv. 269-70 (1960).

50. Ibid.

51. See Frankfurter, Reflections an Reading Statutes, in The Suprenie Court: VIEws FROM INSIDE (A. F. Westin ed. 1961).

52. These questions seem particularly important if the courts are going to defer to the Board's expertise as to what will best promote our national merchant marine. See Grace Line, Inc. v. Federal Maritime Board, 280 F.2d 790, 792-93 (2d Cir. 1960), cert. denicd, 364 U.S. 933 (1961).

53. See Davis, Administrative Law $\S 16.12$ (1958).

54. For the tests showing contract carriage, see the text at notes 14-19 supra. The facts presented to the Federal Maritime Board show that Grace meets these tests, though the Board held that Grace was a common carrier of bananas.

In more than twenty years the Grace Line had carried for only four different shippers of bananas, always under special contract. Joint-Appendix, pp. 185-86, Grace Line, Inc. v. 
of the Shipping Act to allow Grace to discriminate among shippers on regularly scheduled vessels. ${ }^{55}$ Judge Hand's opinion comports with the policy of the statute in so far as it extends the regulation of the Federal Maritime Board to the carriage of goods on regularly scheduled vessels, although some of the goods might have been considered to be transported by contract carriage at common law. ${ }^{56}$ Yet, though there may be valid reasons for federal regulation of all the contract carrier activities of common carriers, the Shipping Act as now constituted does not justify Board jurisdiction over such activities as the leasing out of an entire ship. ${ }^{57}$ On the other hand, of course, it can be argued that in regulating "common carriers" Congress meant to supervise all the activities of regular shipping lines. This approach, however, both ignores the underlying policy of the Act-promotion of scheduled shipping-and disregards the common law meaning of common carrier.

Federal Maritime Board, 263 F.2d 709 (2d Cir. 1959). Bananas require special equipment and handling. They are loaded and unloaded at the shippers' expense and risk, and the refrigeration compartments are under the control of the shippers. Grace asserted without contradiction that it had never expressly held itself out to the general public. Banana Distribs., Inc. v. Grace Line, Inc., 5 F.M.B. 615 (1959), rev'd sub. nom. Grace Line, Inc. v. Federal Maritime Board, 263 F.2d 709 (2d Cir. 1959). Bananas have apparently never before been carried at sea by common carriage. Brief for Petitioner, pp. 8-9, Grace Line, Inc. v. Federal Maritime Board, supra.

55. See Alexander Committee Report 281-314.

56. See text at notes $44-47$ supra.

57. See 53 Cong. REc. 8267-68, 13365 (1916); Hearings on H.R. 14337 Before the House Committee on the Merchant Marine and Fisheries, 64th Cong., 1st Sess. 194-95 (1916). 